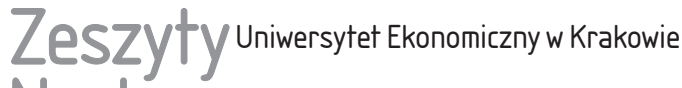 Naukowe
}

\section{Rachunek kosztów jakości w wybranym przedsiębiorstwie usługowym}

\section{Streszczenie}

Cel: Celem artykułu jest zaprezentowanie rachunku kosztów jakości, zasad jego wdrażania i szacowania kosztów jakości, a także próba zastosowania tego rachunku w wybranym przedsiębiorstwie usługowym.

Metodyka badań: Badania empiryczne w zakresie praktycznego zastosowania rachunku kosztów jakości zostało przeprowadzone w jednym z przedsiębiorstw usługowych funkcjonujących na rynku krakowskim.

Wyniki badań: Wdrożenie rachunku kosztów jakości w wybranym przedsiębiorstwie usługowym pozwoliło uporządkować informacje na temat kosztów jakości, wskazać obszary problemowe, a także zależności zachodzące między grupami tych kosztów.

Wnioski: Zaawansowane procesy świadczenia usług, wysokie wymagania klientów dotyczące jakości usług oraz duża konkurencja sprawiają, że informacje kosztowe, których dostarczają tradycyjne systemy rachunkowe, są niewystarczające do podejmowania właściwych decyzji w przedsiębiorstwach. Konieczne staje się zatem wdrożenie nowych systemów rachunku kosztów, które zapewnią wiarygodne informacje o kosztach związanych z jakością. Takim rachunkiem kosztów, dostarczającym rzetelnych informacji, jest rachunek kosztów jakości. Może być on wykorzystywany jako narzędzie wspomagające

Wojciech Sadkowski, Uniwersytet Jagielloński, Wydział Zarządzania i Komunikacji Społecznej, Zakład Finansów i Ekonomii Międzynarodowej, ul. Prof. S. Łojasiewicza 4, 30-348 Kraków, e-mail: wojciech.sadkowski@uj.edu.pl, ORCID: https://orcid.org/0000-0003-2757-6643.

Artykuł udostępniany na licencji Creative Commons Uznanie autorstwa-Użycie niekomercyjne-Bez utworów zależnych 4.0 (CC BY-NC-ND 4.0); https://creativecommons.org/licenses/ by-nc-nd/4.0/ 
proces zarządzania. Jego wdrożenie pozwala zwiększyć efektywność realizowanych procesów, optymalizować koszty i zwiększyć efektywność całej jednostki.

Wkład w rozwój dyscypliny: Uzyskane rezultaty powinny stanowić podstawę teoretyczną i praktyczną do wdrażania tego rachunku w dowolnym przedsiębiorstwie usługowym.

Słowa kluczowe: koszty jakości, procesy, rachunek kosztów jakości, rachunkowość zarządcza.

Klasyfikacja JEL: M41.

\section{Wprowadzenie}

Analiza licznych badań dotyczących kosztów jakości i ich rachunku prowadzi do wniosku, że większość z nich odnosi się do przedsiębiorstw produkcyjnych. W literaturze przedmiotu zauważalny jest natomiast brak odniesienia do przedsiębiorstw usługowych (Sadkowski 2019a, s. 127). Tylko U. Sulowska-Banaś podejmuje próbę opracowania modelu rachunku kosztów jakości przeznaczonego dla szpitali, a więc organizacji świadczących usługi z zakresu ochrony zdrowia (Sulowska-Banaś 2013, s. 140-207; Sulowska-Banaś 2015, s. 37-41).

Głównym celem artykułu jest próba praktycznego wdrożenia rachunku kosztów jakości w wybranym przedsiębiorstwie usługowym. Celami szczegółowymi są: wskazanie miejsca i roli rachunku kosztów jakości w zarządzaniu przedsiębiorstwem, a także przedstawienie zasad jego wdrażania i szacowania kosztów jakości oraz zaprezentowanie i omówienie uzyskanych wyników badań empirycznych dotyczących rachunku kosztów jakości w wybranym przedsiębiorstwie usługowym prowadzonych przez autora.

Do osiągnięcia założonych celów badawczych autor wykorzystał egzemplifikację opracowanego modelu rachunku kosztów jakości w wybranym przedsiębiorstwie usługowym. W prowadzonych badaniach zasadniczą rolę odegrała procedura triangulacji technik badawczych, takich jak: analiza literatury przedmiotu, analiza treści dokumentacji badanego przedsiębiorstwa, obserwacja, analiza danych ilościowych oraz synteza wyników. Skonstruowany przez autora model może być wykorzystywany do oceny efektywności systemów zarządzania przedsiębiorstw usługowych, optymalizacji kosztów i identyfikacji procesów najbardziej obciążonych kosztami związanymi z jakością.

Konstrukcja artykułu jest następująca. Pierwsza część odnosi się do obecnego stanu wiedzy w zakresie rachunku kosztów jakości i obrazuje jego miejsce i rolę w przedsiębiorstwie. W drugiej części autor prezentuje opracowane zasady jego wdrażania, a także sposób szacowania kosztów jakości dla przedsiębiorstw usługowych. Kolejna część to charakterystyka wybranego podmiotu do badań. Ostatnia część zawiera wyniki uzyskane w badaniach empirycznych. Pracę kończą wnioski 
z badań, a także rekomendacje dotyczące przyszłych działań w tym obszarze badawczym.

\section{Rachunek kosztów jakości - jego miejsce i rola w przedsiębiorstwie}

Działalność usługowa, tak jak każda inna działalność gospodarcza, wiąże się z ponoszeniem kosztów. Duża część kosztów przeznaczonych na realizację usługi dotyczy jakości, która z punktu widzenia klienta ma fundamentalne znaczenie w odbiorze świadczonej usługi. Dlatego też istotne dla przedsiębiorstwa jest oszacowanie i ujawnienie kosztów jakości, które ukrywają się w realizowanych procesach. Uporządkowanie tych kosztów pozwala jednostce bardziej świadomie podchodzić do problemu jakości i efektywności procesów.

Do pomiaru kosztów związanych z zapewnieniem jakości wykorzystuje się rachunek kosztów jakości, który jest systemem ewidencji, analizy i oceny tych kosztów. Dla podmiotów zorientowanych na jakość rachunek ten stanowi jedno z ważniejszych narzędzi decyzyjnych (Balon 2012, s. 447). Dostarcza on informacji, które są wykorzystywane przez menedżerów do podejmowania decyzji dotyczących działań poprawy jakości, optymalizacji kosztów jakości, a także eliminacji słabych stron (Ciechan-Kujawa 2005, s. 83-85). Rachunek kosztów jakości to ważny element analizy ekonomicznej, który usprawnia zarządzanie organizacją, daje możliwość oceny konieczności poniesienia kosztu i jego wpływu na poprawę efektywności procesów (Rehacek 2018, s. 8-13).

Do najważniejszych korzyści związanych z wprowadzeniem rachunku kosztów jakości należy zaliczyć (Murumkar, Teli i Loni 2018, s. 156-162):

- uzyskanie informacji o wysokości kosztów jakości powstających w procesach realizowanych przez organizację,

- identyfikację przyczyn powstawania niezgodności i błędów,

- identyfikację procesów, w których ponoszone są najwyższe koszty jakości,

- aktywizację wszystkich pracowników do uczestnictwa w procesie zarządzania jakością,

- pomiar i ocenę efektywności i skuteczności systemów zarządzania,

- obniżenie poziomu kosztów jakości,

- dążenie do optymalizacji struktury kosztów jakości.

Do najważniejszych barier wdrożenia rachunku kosztów jakości zalicza się brak otwartości i chęci współpracy w przedsiębiorstwach prywatnych, dla których temat jakości i pojawiających się nieprawidłowości to element polityki wewnętrznej i które nie są zainteresowane udostępnieniem takich danych (Ciechan-Kujawa 2004, s. 32-35). Poważną przeszkodą może być również niepro- 
wadzenie pełnej księgowości oraz brak wdrożonego systemu zarządzania jakością i certyfikatów ISO.

Rachunek kosztów jakości to jedno z nowoczesnych narzędzi wspierających zarządzanie. Umożliwia pomiar, ewidencję, rejestrację, grupowanie, przetwarzanie, analizowanie i interpretowanie kosztów jakości, a także ich optymalizację. Odpowiada za identyfikację działań i procesów problemowych (Sadkowski 2019b, s. 19). Jest rachunkiem decyzyjnym, który może przyczynić się do poprawy jakości w organizacji, a także stanowi ważny element w ocenie efektywności systemów zarządzania.

\section{Zasady wdrażania rachunku kosztów jakości i szacowania kosztów jakości}

Aby zrozumieć istotę i zasady wdrażania rachunku kosztów jakości w przedsiębiorstwach usługowych, należy przyjrzeć się schematowi struktury kosztów jakości, który determinuje ich szacowanie. Schemat ten pokazuje elementy mające wpływ na kształtowanie się struktury kosztów jakości w organizacjach usługowych, a także identyfikuje kategorie tych kosztów (rys. 1).

Zaproponowany schemat opiera się na założeniu, że źródłem kosztów jakości w przedsiębiorstwach usługowych są procesy (podstawowe, pomocnicze i zarządzania), które realizują one w ramach przyjętego systemu zarządzania. Wielkość podmiotu i rodzaj świadczonych usług determinuje poziom złożoności procesów, a także strukturę kosztów jakości. Na procesy wpływają również inne czynniki wewnętrzne (organizacyjno-ekonomiczne, zasobowe i innowacyjne) i zewnętrzne (regulacje prawne, czynniki społeczno-rynkowe, zdarzenia losowe). Autor wyróżnił trzy kategorie kosztów jakości: koszty zgodności (koszty profilaktyki i oceny), koszty niezgodności (koszty błędów wewnętrznych i zewnętrznych) oraz pozostałe koszty jakości. Najważniejszym działaniem związanym z szacowaniem tych kosztów jest właściwa identyfikacja miejsc ich powstawania, co pozwala na późniejszą ich ewidencję na odpowiednich kontach księgowych układu rodzajowego i/lub kalkulacyjnego.

Zarządzający przedsiębiorstwem przygotowującym się do wdrożenia rachunku kosztów jakości powinni mieć na uwadze, że do osiągnięcia sukcesu konieczna jest pełna wiarygodność i otwartość. Kolejnymi etapami, które należy zrealizować przy implementacji i prowadzeniu rachunku, są:

- etap I: utworzenie zespołu zadaniowego ds. jakości, który będzie odpowiadał za zorganizowanie podstaw funkcjonowania systemu rachunku kosztów jakości,

- etap II: identyfikacja działań w procesach, które odpowiadają za generowanie kosztów jakości, 


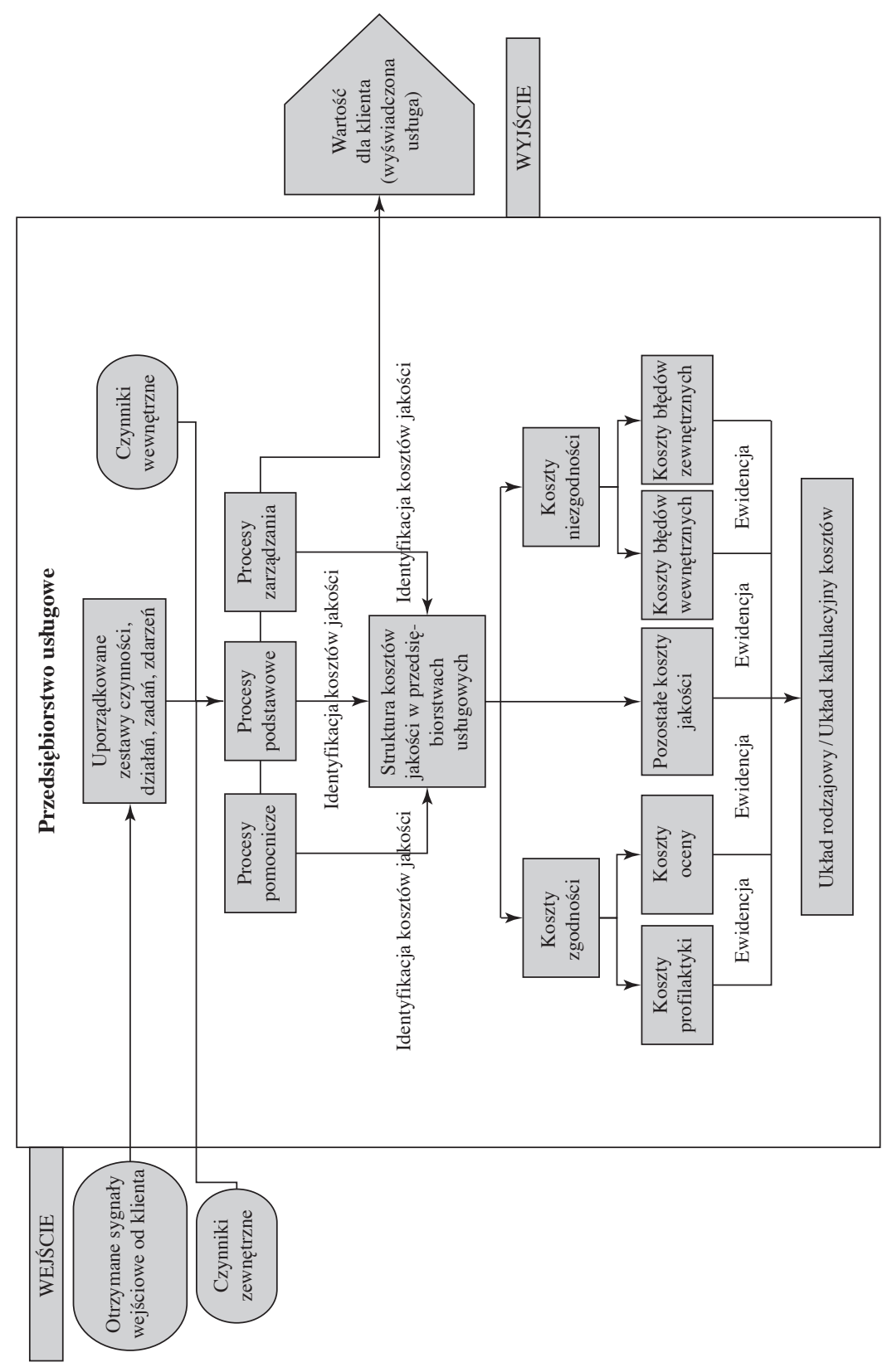

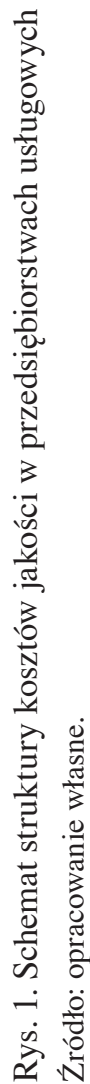


- etap III: ustalenie elementów kosztów jakości, które mogą być rejestrowane w obowiązującym systemie rachunkowym,

- etap IV: wprowadzenie zarządzenia o zastosowaniu rachunku kosztów jakości,

- etap V: szacowanie kosztów jakości i ich systematyczna ewidencja w systemie rachunkowym organizacji,

- etap VI: analiza kosztów jakości obejmująca analizę ich struktury, dynamiki zmian oraz analizę wskaźnikową,

- etap VII: sporządzenie raportu o kosztach jakości i przygotowanie rekomendacji dotyczących podjęcia działań korygujących,

- etap VIII: ocena skuteczności podjętych działań korygujących.

Do szacowania kosztów jakości w przedsiębiorstwach usługowych autor rekomenduje wykorzystanie przygotowanego formularza szacowania kosztów, który został zaprezentowany w tabeli 1.

Tabela 1. Formularz szacowania kosztów jakości w przedsiębiorstwach usługowych (wzór)

\begin{tabular}{|c|c|l|c|l|l|}
\hline $\begin{array}{c}\text { Nazwa } \\
\text { procesu }\end{array}$ & Nazwa kosztu & $\begin{array}{c}\text { Kategoria } \\
\text { kosztu jakości }\end{array}$ & $\begin{array}{c}\text { Wysokość } \\
\text { kosztu } \\
\text { w badanym } \\
\text { okresie }\end{array}$ & $\begin{array}{c}\text { Dokument } \\
\text { źródłowy }\end{array}$ & $\begin{array}{c}\text { Dodatkowe } \\
\text { informacje }\end{array}$ \\
\hline Proces nr 1 & Koszt nr 1 & & & & \\
\cline { 2 - 6 } & Koszt nr 2 & & & & \\
\cline { 2 - 6 } & Koszty nr $n$ & & & & \\
\hline Proces nr 2 & Koszt nr 1 & & & & \\
\cline { 2 - 6 } & Koszt nr 2 & & & & \\
\hline & Koszt nr $n$ & & & & \\
\hline Proces nr $n$ & Koszt nr 1 & & & & \\
\cline { 2 - 6 } & Koszt nr 2 & & & & \\
\cline { 2 - 6 } & Koszt nr $n$ & & & & \\
\hline
\end{tabular}

Źródło: opracowanie własne.

Z kolei w analizie kosztów jakości skutecznymi narzędziami badawczymi będą: macierz kosztów jakości, diagram Pareta-Lorenza, a także tabela wskaźników kosztów jakości. Przegląd tych narzędzi znajduje się w dalszej części artykułu.

Przygotowany formularz szacowania kosztów jakości będzie stanowił podstawę do opracowania macierzy kosztów jakości, która została przedstawiona w tabeli 2. Macierz kosztów jakości pomoże zidentyfikować strukturę tych kosztów w badanym okresie, a także ustalić procesy i grupy procesów generujące najwyższe koszty związane z jakością. Uzyskane informacje będzie można wykorzystać do wskazania obszarów, w których pojawiają się błędy i niezgodności, oraz tych, które zapewniają 
odpowiedni poziom jakości. Wiedza ta pozwoli na efektywniejsze zarządzanie procesami w przedsiębiorstwie, optymalizację kosztów, a także eliminację błędów. Zaproponowana macierz może być narzędziem, które będzie wspomagało zarządzanie i zapewni wiarygodne informacje o wysokości kosztów jakości w realizowanych procesach.

Tabela 2. Macierz kosztów jakości

\begin{tabular}{|l|l|l|l|l|l|}
\hline \multicolumn{1}{|c|}{ Koszty jakości } & $\begin{array}{c}\text { Procesy } \\
\text { podstawowe } \\
\text { (operacyjne) }\end{array}$ & $\begin{array}{c}\text { Procesy } \\
\text { zarządzania } \\
\text { (strategiczne) }\end{array}$ & $\begin{array}{c}\text { Procesy } \\
\text { pomocnicze }\end{array}$ & Razem & $\begin{array}{c}\text { Analiza } \\
\text { pionowa } \\
\text { kosztów } \\
\text { jakości }\end{array}$ \\
\hline Koszty profilaktyki & & & & & \\
\hline $\begin{array}{l}\text { Koszty oceny } \\
\text { wewnętrzęnych }\end{array}$ & & & & & \\
\hline $\begin{array}{l}\text { Koszty błędów } \\
\text { zewnętrznych }\end{array}$ & & & & & \\
\hline Pozostałe koszty jakości & & & & & \\
\hline Razem & & & & & \\
\hline $\begin{array}{l}\text { Analiza pionowa } \\
\text { procesów generujących } \\
\text { kosztów jakości }\end{array}$ & & & & & \\
\hline
\end{tabular}

Źródło: opracowanie własne.

Kolejnym narzędziem badawczym jest diagram Pareta-Lorenza, który wykorzystuje się do grupowania danych i prezentacji ich udziału w całkowitym wyniku. Wskazuje on najistotniejsze czynniki mające wpływ na badane zjawisko (Stadnicka 2019, s. 146-167). W analizie kosztów jakości diagram ten można zastosować do identyfikacji nieprawidłowości powstających w badanym przedsiębiorstwie.

Ostatnim z prezentowanych narzędzi badawczych są wskaźniki kosztów jakości, które zostały zebrane w tabeli 3 .

Tabela 3. Wskaźniki kosztów jakości

\begin{tabular}{|l|l|}
\hline \multicolumn{1}{|c|}{ Nazwa wskaźnika } & \multicolumn{1}{c|}{ Wzór } \\
\hline $\begin{array}{l}\text { Wskaźnik udziału kosztów jakości w kosztach } \\
\text { ogółem }\end{array}$ & $\begin{array}{l}\text { WuKJwKO }=(\text { koszty jakości/koszty } \\
\text { ogółem }) \cdot 100 \%\end{array}$ \\
$\begin{array}{l}\text { Wskaźnik udziału kosztów zgodności w kosz- } \\
\text { tach jakości }\end{array}$ & $\begin{array}{l}\text { WKZ }=[(\text { koszty profilaktyki }+ \text { koszty oceny }) / \\
\text { koszty jakości }] \cdot 100 \%\end{array}$ \\
\hline $\begin{array}{l}\text { Wskaźnik udziału kosztów niezgodności } \\
\text { w kosztach jakości }\end{array}$ & $\begin{array}{l}\text { WKNZ }=[(\text { koszty błędów wewnętrznych } \\
+ \text { koszty błędów zewnętrznych }) / \text { koszty } \\
\text { jakości }] \cdot 100 \%\end{array}$ \\
\hline
\end{tabular}


cd. tabeli 3

\begin{tabular}{|l|l|}
\hline \multicolumn{1}{|c|}{ Nazwa wskaźnika } & \multicolumn{1}{c|}{ Wzór } \\
\hline $\begin{array}{l}\text { Wskaźnik udziału kosztów profilaktyki } \\
\text { w kosztach jakości }\end{array}$ & $\begin{array}{l}\text { WKP }=(\text { koszty profilaktyki/koszty } \\
\text { jakości }) \cdot 100 \%\end{array}$ \\
\hline $\begin{array}{l}\text { Wskaźnik udziału kosztów oceny w kosztach } \\
\text { jakości }\end{array}$ & $\begin{array}{l}\text { WKO }=(\text { koszty oceny/koszty } \\
\text { jakości }) \cdot 100 \%\end{array}$ \\
\hline $\begin{array}{l}\text { Wskaźnik udziału kosztów błędów wewnętrz- } \\
\text { nych w kosztach jakości }\end{array}$ & $\begin{array}{l}\text { WKBw }=(\text { koszty błędów wewnętrznych/ } \\
\text { koszty jakości }) \cdot 100 \%\end{array}$ \\
\hline $\begin{array}{l}\text { Wskaźnik udziału kosztów błędów zewnętrz- } \\
\text { nych w kosztach jakości }\end{array}$ & $\begin{array}{l}\text { WKBz }=(\text { koszty błędów zewnętrznych/koszty } \\
\text { jakości }) \cdot 100 \%\end{array}$ \\
\hline $\begin{array}{l}\text { Wskaźnik udziału liczby niezgodności } \\
\text { w kosztach jakości }\end{array}$ & $\begin{array}{l}\text { WuN }=(\text { liczba niezgodności/ } \\
\text { koszty jakości }) \cdot 100 \%\end{array}$ \\
\hline $\begin{array}{l}\text { Wskaźnik udziału kosztów jakości w przycho- } \\
\text { dach ze sprzedaży }\end{array}$ & $\begin{array}{l}\text { WuKJwP }=(\text { koszty jakości/przychody } \\
\text { ze sprzedaży }) \cdot 100 \%\end{array}$ \\
\hline $\begin{array}{l}\text { Wskaźnik udziału kosztów jakości w zysku } \\
\text { netto }\end{array}$ & $\begin{array}{l}\text { WuKJwZN }=(\text { koszty jakości/zysk } \\
\text { netto }) \cdot 100 \%\end{array}$ \\
\hline $\begin{array}{l}\text { Wskaźnik udziału kosztów niezgodności } \\
\text { w zysku netto }\end{array}$ & $\begin{array}{l}\text { WKNZZN }=[(\text { koszty błędów wewnętrznych } \\
+ \text { koszty błędów zewnętrznych }) / \text { zysk } \\
\text { netto] } \cdot 100 \%\end{array}$ \\
\hline $\begin{array}{l}\text { Wskaźnik udziału kosztów jakości w kosztach } \\
\text { operacyjnych }\end{array}$ & $\begin{array}{l}\text { WuKJwKO }=(\text { koszty jakości/koszty } \\
\text { operacyjne }) \cdot 100 \%\end{array}$ \\
\hline
\end{tabular}

Źródło: opracowanie własne na podstawie (Wójcik 2014, s. 79-80).

Analiza wskaźnikowa kosztów jakości ma dostarczyć informacji o kształtowaniu się tych kosztów w ustalonych przekrojach. Skalkulowane wskaźniki umożliwią ustalenie zależności zachodzących pomiędzy poszczególnymi grupami kosztów jakości, a także wpływ kosztów jakości na wyniki finansowe i rachunek zysków i strat badanego przedsiębiorstwa.

Przedstawione założenia rachunku kosztów jakości i narzędzia do szacowania kosztów jakości zostały wykorzystane w podjętej próbie zastosowania rachunku kosztów jakości w wybranym przedsiębiorstwie usługowym.

\section{Badania zasadnicze}

\subsection{Charakterystyka badanego przedsiębiorstwa usługowego}

Badane przedsiębiorstwo jest spółką akcyjną, której kapitał zakładowy wynosi 208457000 zł. Jego historia sięga dnia 14 lutego 1901 r. i uroczystego uruchomienia wodociągu na Bielanach. Bardzo ważną datą w działalności spółki był 1951 r., w którym nastąpiło przekształcenie w przedsiębiorstwo państwowe. 
W 1991 r. jednostka została przekształcona w jednoosobową spółkę akcyjną i w takiej formie prawnej funkcjonuje do dzisiaj (https://www.wodociagi.krakow. $\mathrm{pl} /$ historia.html, data dostępu: 31.01.2020). Pierwsze dwie dekady XXI w. to okres ciągłej modernizacji i rozbudowy infrastruktury, które były możliwe dzięki wykorzystaniu środków pochodzących z projektów Unii Europejskiej. Według stanu na 31 grudnia 2019 r. spółka posiada w swoim majątku następujące składniki: cztery zakłady uzdatniania wody, dwa zakłady oczyszczania ścieków, pięć oczyszczalni lokalnych, jedną stację termicznej utylizacji osadów, jedno centralne laboratorium, 47 zbiorników wodociągowych, 25 hydroforni, trzy przepompownie wodociągowe, 80 przepompowni ścieków, dwie stacje zlewcze, $2280 \mathrm{~km}$ sieci wodociągowej oraz $1935 \mathrm{~km}$ sieci kanalizacyjnej (https://wodociagi.krakow.pl/o-firmie/infrastruktura. html, data dostępu: 31.01.2020).

W 2018 r. średnioroczne zatrudnienie w badanym przedsiębiorstwie wyniosło 1140 pracowników: $45,2 \%$ to pracownicy umysłowi, a 54,8\% pracownicy fizyczni (Raport roczny... 2019, s. 25). Wysokość przychodów spółki w 2018 r. osiągnęła poziom $505 \mathrm{mln}$ zł, a koszty ogółem zamknęły się w kwocie 445,8 mln zł. Suma bilansowa na dzień 31 grudnia 2018 r. była równa 1,95 mld zł. W aktywach dominowały aktywa trwałe, które stanowiły 1,8 mld zł, a w pasywach kapitał własny w wysokości 1,2 mld zł. Zysk netto za 2018 r. ukształtował się na poziomie $46,6 \mathrm{mln}$ zł i był wyższy od planowanego o 31,6\%. Analiza przepływów pieniężnych wykazała, że na koniec roku obrotowego 2018 stan środków pieniężnych wyniósł 33,9 mln zł, z czego przepływy netto z działalności operacyjnej to 116,4 mln zł, z działalności inwestycyjnej - 121,1 mln zł, a z działalności finansowej - 3,8 mln zł (Raport roczny... 2019, s. 7).

Głównym przedmiotem działalności przedsiębiorstwa jest pobór, uzdatnianie i dostarczanie wody. Pozostała działalność obejmuje m.in.: odprowadzenie, oczyszczanie i kontrolę ścieków, usługi w zakresie budowy i remontów obiektów i sieci wodociągowo-kanalizacyjnej oraz instalacji wodno-kanalizacyjnej, a także usługi pogotowia wodociągowego (https://bip.mpwik.krakow.pl/katalog/strona,32. html\#accept, data dostępu: 31.01.2020).

Spółka bardzo dużą wagę przywiązuje do ekologii i działań, które mają na celu ochronę środowiska; są to m.in.: nadzór nad ujęciami wody, monitoring wód, oczyszczanie ścieków, nadzór nad jakością ścieków przemysłowych, budowa i modernizacja sieci kanalizacyjnych, edukacja ekologiczna dzieci i młodzieży, farma fotowoltaiczna czy kogeneracja (Raport roczny... 2019, s. 29). 


\subsection{Wyniki zastosowania rachunku kosztów jakości w wybranym przedsiębiorstwie usługowym}

Opracowanie systemu rachunku kosztów jakości dla badanego przedsiębiorstwa rozpoczęto od zidentyfikowania procesów, które są w nim realizowane w związku ze świadczeniem usług. Na działalność przedsiębiorstwa składają się procesy operacyjne, które wspierane są przez procesy strategiczne i pomocnicze. Do procesów operacyjnych zaliczono: grupę procesów obsługi klienta, grupę procesów rozwoju sieci, grupę procesów gospodarki wodomierzowej, grupę procesów sprzedaży, grupę procesów produkcji wody, grupę procesów zakupów, grupę procesów dysponowania wodą, grupę procesów monitorowania produkcji oraz grupę procesów odbioru i oczyszczania ścieków. Do procesów strategicznych zaliczono: grupę procedur doskonalenia zintegrowanego systemu zarządzania oraz grupę procesów zarządzania i planowania. Natomiast procesy pomocnicze tworzy grupa procesów zarządzania infrastrukturą techniczną i grupa procesów zarządzania personelem.

Do poszczególnych 13 grup procesów w zintegrowanym systemie zarządzania badanego przedsiębiorstwa zostały przypisane odpowiednie procesy. Zgodnie z uzyskanymi informacjami badany podmiot realizuje 41 procesów. Ich szczegótowe zestawienie prezentuje tabela 4 .

Tabela 4. Procesy realizowane w badanym przedsiębiorstwie

\begin{tabular}{|c|c|}
\hline Grupa & Nazwa procesu \\
\hline $\begin{array}{l}\text { Grupa procedur dosko- } \\
\text { nalenia zintegrowanego } \\
\text { systemu zarządzania }\end{array}$ & Procedura audytów wewnętrznych \\
\hline \multirow{3}{*}{$\begin{array}{l}\text { Grupa procesów } \\
\text { zarządzania } \\
\text { i planowania }\end{array}$} & Proces planowania zadań inwestycyjnych \\
\hline & Proces planowania prac konserwacyjnych i remontów bieżących \\
\hline & Proces planowania remontów budowlanych \\
\hline \multirow{4}{*}{$\begin{array}{l}\text { Grupa procesów } \\
\text { obsługi klienta }\end{array}$} & Proces obsługi korespondencji \\
\hline & Proces obsługi reklamacji \\
\hline & Proces windykacji \\
\hline & $\begin{array}{l}\text { Proces zawierania umów o zaopatrzenie w wodę i (lub) odprowadza- } \\
\text { nie ścieków }\end{array}$ \\
\hline \multirow[t]{4}{*}{$\begin{array}{l}\text { Grupa procesów } \\
\text { rozwoju sieci }\end{array}$} & $\begin{array}{l}\text { Proces wydawania warunków przyłączenia do sieci wodociągowej } \\
\text { i kanalizacyjnej }\end{array}$ \\
\hline & Proces odbioru przyłączy domowych \\
\hline & $\begin{array}{l}\text { Proces nadzoru i odbioru sieci wykonywanej przez inwestorów } \\
\text { zewnętrznych }\end{array}$ \\
\hline & $\begin{array}{l}\text { Proces wydawana warunków przyłączenia do sieci wodociągowej } \\
\text { i kanalizacyjnej }\end{array}$ \\
\hline
\end{tabular}


cd. tabeli 4

\begin{tabular}{|c|c|}
\hline Grupa & Nazwa procesu \\
\hline \multirow{2}{*}{$\begin{array}{l}\text { Grupa procesów } \\
\text { gospodarki } \\
\text { wodomierzowej }\end{array}$} & Proces prowadzenia remontów i legalizacji wodomierzy \\
\hline & Proces wstawiania, wymiany i usuwania awarii wodomierzy \\
\hline $\begin{array}{l}\text { Grupa procesów } \\
\text { sprzedaży }\end{array}$ & Proces realizacji planu sprzedaży wody i odprowadzania ścieków \\
\hline \multirow{3}{*}{$\begin{array}{l}\text { Grupa procesów } \\
\text { produkcji wody }\end{array}$} & Proces uzdatniania wody \\
\hline & Proces przesyłu wody \\
\hline & Proces odwadniania osadów \\
\hline $\begin{array}{l}\text { Grupa procesów } \\
\text { zakupów }\end{array}$ & Proces zakupów i dostawy materiałów oraz oceny dostawców \\
\hline \multirow{2}{*}{$\begin{array}{l}\text { Grupa procesów } \\
\text { dysponowania wodą }\end{array}$} & Proces rozdziału wody do stref rozbioru \\
\hline & Proces obsługi bieżącej sieci i dystrybucji wody \\
\hline \multirow{2}{*}{$\begin{array}{l}\text { Grupa procesów } \\
\text { monitorowania } \\
\text { produkcji }\end{array}$} & Proces badania jakości wody \\
\hline & Proces badania jakości ścieków \\
\hline \multirow{9}{*}{$\begin{array}{l}\text { Grupa procesów } \\
\text { zarządzania } \\
\text { infrastrukturą } \\
\text { techniczną }\end{array}$} & Proces realizacji konserwacji i remontów bieżących \\
\hline & Proces realizacji zadań inwestycyjnych i remontów budowlanych \\
\hline & $\begin{array}{l}\text { Proces przeglądów oraz napraw bieżących i usuwania awarii sieci } \\
\text { wodociągowej }\end{array}$ \\
\hline & Proces usuwania awarii sieci tranzytowej \\
\hline & Proces przygotowania inwestycji \\
\hline & Proces zarządzania systemem informatycznym \\
\hline & Proces gospodarowania środkami transportowymi \\
\hline & $\begin{array}{l}\text { Proces BHP przy uzdatnianiu, dystrybucji wody i oczyszczaniu } \\
\text { ścieków }\end{array}$ \\
\hline & Proces nadzoru i eksploatacji budowlanych \\
\hline $\begin{array}{l}\text { Grupa procesów } \\
\text { zarządzania personelem }\end{array}$ & Proces szkoleń pracowników \\
\hline \multirow{8}{*}{$\begin{array}{l}\text { Grupa procesów } \\
\text { odbioru i oczyszczania } \\
\text { ścieków }\end{array}$} & Proces przeglądów oraz bieżącej eksploatacji sieci kanalizacyjnej \\
\hline & Proces usuwania awarii sieci kanalizacyjnej \\
\hline & Proces oczyszczania ścieków z oczyszczalni lokalnych \\
\hline & Proces oczyszczania ścieków w ZOŚ Płaszów \\
\hline & Proces gospodarki odpadami w ZOŚ Płaszów \\
\hline & Proces oczyszczania ścieków w ZOŚ Kujawy \\
\hline & $\begin{array}{l}\text { Proces przeróbki osadów i gospodarki odpadam technologicznymi } \\
\text { w ZOŚ Kujawy }\end{array}$ \\
\hline & Proces termicznego przekształcana osadów ściekowych \\
\hline
\end{tabular}

Źródło: opracowanie własne na podstawie dokumentów wewnętrznych badanego przedsiębiorstwa. 
Do najważniejszych procesów realizowanych przez badane przedsiębiorstwo zaliczany jest proces obsługi bieżącej sieci i dystrybucji wody, który składa się z odpowiednich podprocesów.

Zidentyfikowane grupy procesów i poszczególne procesy pozwoliły na ustalenie miejsc powstawania kosztów jakości w badanym podmiocie i przygotowanie formularza szacowania kosztów jakości, który został przekazany do skonsultowania z działem planowania i controllingu. W wyniku konsultacji i analiz otrzymano formularz z oszacowanymi kosztami, na podstawie którego autor przygotował macierz kosztów jakości (tabela 5). Za horyzont czasowy do badań empirycznych przyjęto okres jednego roku sprawozdawczego (2018 r.).

Tabela 5. Macierz kosztów jakości badanego przedsiębiorstwa

\begin{tabular}{|l|c|c|c|c|c|}
\hline \multicolumn{1}{|c|}{ Koszty jakości } & $\begin{array}{c}\text { Procesy } \\
\text { podstawowe } \\
\text { (operacyjne) } \\
\text { (w tys. zł) }\end{array}$ & $\begin{array}{c}\text { Procesy } \\
\text { zarządzania } \\
\text { (strategiczne) } \\
\text { (w tys. zł) }\end{array}$ & $\begin{array}{c}\text { Procesy } \\
\text { pomocnicze } \\
\text { (w tys. zł) }\end{array}$ & $\begin{array}{c}\text { Razem } \\
\text { (w tys. zł) }\end{array}$ & $\begin{array}{c}\text { Analiza } \\
\text { pionowa } \\
\text { kosztów } \\
\text { jakości } \\
\text { (w \%) }\end{array}$ \\
\hline Koszty profilaktyki & 266305 & 811 & 252 & 267368 & 92,84 \\
\hline Koszty oceny & 5520 & 11 & 1366 & 6897 & 2,39 \\
\hline $\begin{array}{l}\text { Koszty błędów } \\
\text { wewnętrznych }\end{array}$ & 13724,2 & - & - & 13724,2 & 4,77 \\
\hline $\begin{array}{l}\text { Koszty błędów } \\
\text { zewnętrznych }\end{array}$ & 1 & - & - & 1 & 0,0002 \\
\hline $\begin{array}{l}\text { Pozostałe koszty } \\
\text { jakości }\end{array}$ & - & - & - & 0 & 0,00 \\
\hline Razem & 285550 & 822 & 1618 & 287989,2 & 100 \\
\hline $\begin{array}{l}\text { Analiza pionowa pro- } \\
\text { cesów generujących } \\
\text { kosztów jakości (w \%) }\end{array}$ & 99,15 & 0,29 & 0,56 & 100 & $\times$ \\
\hline
\end{tabular}

Źródło: opracowanie własne na podstawie dokumentów wewnętrznych badanego przedsiębiorstwa.

Zidentyfikowane koszty jakości w 2018 r. wyniosły 287,989 mln zł, z czego prawie 93\% (267,368 mln zł) stanowiły koszty profilaktyki, 2,39\% (6,897 mln zł) - koszty oceny, a koszty błędów wewnętrznych niecałe 5\% (13,724 mln zł) wszystkich kosztów jakości. Natomiast koszty błędów zewnętrznych w wysokości 1 tys. zł dawały tylko 0,0002\% całkowitych kosztów jakości. Najbardziej obciążone kosztami związanymi z jakością są procesy podstawowe $(99,15 \%)$, z dominującymi grupami procesów odbioru i oczyszczania ścieków $(56,4 \%)$ oraz procesów produkcji wody $(39,52 \%)$. Koszty błędów wewnętrznych i zewnętrznych zostały zidentyfikowane tylko $\mathrm{w}$ procesach podstawowych $\mathrm{w}$ grupach: procesów produkcji wody, procesów odbioru i oczyszczania ścieków, a także procesów obsługi klienta. 
Procesy pomocnicze generują tylko $0,56 \%$, a procesy zarządzania $0,29 \%$ kosztów jakości. Wszystkie zidentyfikowane koszty jakości w badanym przedsiębiorstwie zebrano i uporządkowano w tabeli 6.

Tabela 6. Model strukturalny kosztów jakości badanego przedsiębiorstwa

\begin{tabular}{|c|c|}
\hline \multicolumn{2}{|c|}{ Koszty zgodności } \\
\hline koszty profilaktyki & koszty oceny \\
\hline $\begin{array}{l}\text { - koszty certyfikacji systemu zarządzania } \\
\text { jakością } \\
\text { - koszty utrzymania zespołu ds. jakości } \\
\text { - koszty biura planowania i controllingu } \\
\text { - koszty eksploatacji wodomierzy } \\
\text { - koszty wstawiania wodomierzy } \\
\text { - koszty uzdatniania wody (koszty materia- } \\
\text { łów do uzdatniania wody: PAX 16, PAX 19, } \\
\text { chloryn sodowy, podchloryn sodu, węgiel } \\
\text { aktywny, chlor ciekły } \\
\text { - koszty energii } \\
\text { - koszty remontów } \\
\text { - koszty utylizacji } \\
\text { - koszty ochrony zbiornika } \\
\text { - koszty amortyzacji } \\
\text { - koszty przesyłu wody (koszty sieci rozdziel- } \\
\text { czej i koszty magistrali) } \\
\text { - koszty opłat środowiskowych } \\
\text { - koszty szkoleń pracowników (koszty szkoleń } \\
\text { obligatoryjnych, laboratoryjnych, BHP oraz } \\
\text { BHP na wysokościach) } \\
\text { - koszty eksploatacji sieci kanalizacyjnej } \\
\text { - koszty oczyszczania ścieków } \\
\text { - koszty stacji termicznej utylizacji osadów }\end{array}$ & $\begin{array}{l}\text { - koszty audytów wewnętrznych } \\
\text { - koszty odbioru przyłączy do sieci wodocią- } \\
\text { gowej i kanalizacyjnej (koszty płukania sieci } \\
\text { wodociągowej, koszty próby technicznej, } \\
\text { koszty dojazdu) } \\
\text { - koszty nadzoru i odbioru sieci wykonywanej } \\
\text { przez inwestorów zewnętrznych } \\
\text { - koszty badania jakości wody } \\
\text { - koszty badania jakości ścieków } \\
\text { - koszty zarządzania systemem informatycz- } \\
\text { nym (koszty monitoringu funkcjonowania } \\
\text { zakładów uzdatniania wody, oczyszczalni, } \\
\text { sieci) }\end{array}$ \\
\hline \multicolumn{2}{|c|}{ Koszty niezgodności } \\
\hline koszty błędów wewnętrznych & koszty błędów zewnętrznych \\
\hline $\begin{array}{l}\text { - koszty usuwania awarii sieci wodociągowych } \\
\text { - koszty usuwania awarii sieci kanalizacyjnych }\end{array}$ & $\begin{array}{l}\text { - koszty obsługi reklamacji dotyczących } \\
\text { jakości wody } \\
\text { - koszty obsługi zgłoszeń (dotyczących } \\
\text { wycieków wody, brudnej wody, konieczności } \\
\text { dokonania porządków po awariach, pracy } \\
\text { wodomierzy, sieci kanalizacyjnej) }\end{array}$ \\
\hline
\end{tabular}

Źródło: opracowanie własne na podstawie dokumentów wewnętrznych badanego przedsiębiorstwa.

Do analizy nieprawidłowości zidentyfikowanych w badanej organizacji w $2018 \mathrm{r}$. został wykorzystany diagram Pareta-Lorenza (rys. 2). 
Największe nieprawidłowości w przedsiębiorstwie w 2018 r. dotyczyły głównie sieci kanalizacyjnej (3362) i wycieków wody (1504). Z czego rzeczywiście zdiagnozowanych i usuniętych awarii sieci kanalizacyjnej było 66, a sieci wodociągowej 1504. Łączna suma zgłoszeń nieprawidłowości i reklamacji w badanym roku wyniosła 5309, co daje średnio 14,5 zgłoszenia na dzień.

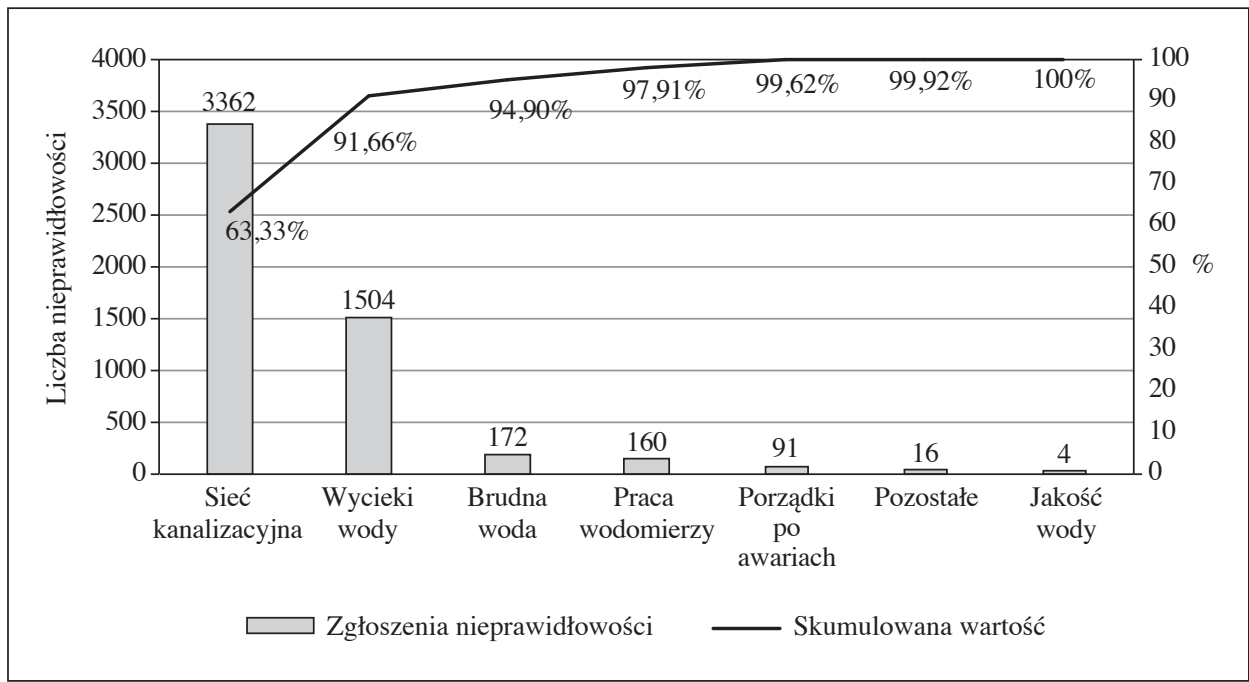

Rys. 2. Diagram Pareta-Lorenza nieprawidłowości badanego przedsiębiorstwa dla 2018 r. Źródło: opracowanie własne na podstawie dokumentów wewnętrznych badanego przedsiębiorstwa.

Ostatnim etapem analizy kosztów jakości była kalkulacja 12 wskaźników kosztów jakości, która została przeprowadzona na podstawie danych zawartych w macierzy kosztów jakości, a także danych finansowych z raportu rocznego spółki za 2018 r. Wyniki tej analizy zostały zebrane w tabeli 7.

Najważniejsze wnioski z analizy wskaźnikowej kosztów jakości badanego przedsiębiorstwa to:

- wysoki udział $(64,6 \%)$ kosztów jakości w kosztach całkowitych przedsiębiorstwa, a także w kosztach operacyjnych $(66,59 \%)$,

- dominacja kosztów zgodności nad kosztami niezgodności $(95,23 \%$ w stosunku do 4,77\%), co świadczy o bardzo niewielkiej liczbie błędów w realizowanych procesach i bardzo efektywnej strukturze kosztów jakości,

- bardzo niski udział liczby niezgodności w stosunku do całkowitych kosztów jakości $(1,84 \%)$,

- koszty jakości stanowią prawie $62 \%$ wszystkich przychodów ze sprzedaży, a także ponad sześciokrotnie przekraczają zysk netto badanego podmiotu 
$(618,25 \%)$, co pozwala stwierdzić, że mają one duży wpływ na jej wyniki finansowe i rachunek zysków i strat,

- prawie 30\% zysku netto to koszty niezgodności, wzrost tego wskaźnika w kolejnych latach będzie niepokojącym zjawiskiem.

Tabela 7. Analiza wskaźnikowa kosztów jakości badanego przedsiębiorstwa w 2018 r.

\begin{tabular}{|l|c|}
\hline \multicolumn{1}{|c|}{ Wskaźnik } & Wartość wskaźnika (w \%) \\
\hline Wskaźnik udziału kosztów jakości w kosztach ogółem & 64,60 \\
\hline Wskaźnik udziału kosztów zgodności w kosztach jakości & 95,23 \\
\hline Wskaźnik udziału kosztów niezgodności w kosztach jakości & 4,77 \\
\hline Wskaźnik udziału kosztów profilaktyki w kosztach jakości & 92,84 \\
\hline Wskaźnik udziału kosztów oceny w kosztach jakości & 2,39 \\
\hline Wskaźnik udziału kosztów błędów wewnętrznych w kosztach jakości & 4,77 \\
\hline $\begin{array}{l}\text { Wskaźnik udziału kosztów błędów zewnętrznych } \\
\text { w kosztach jakości }\end{array}$ & 0,0002 \\
\hline Wskaźnik udziału liczby niezgodności w kosztach jakości & 1,84 \\
\hline $\begin{array}{l}\text { Wskaźnik udziału kosztów jakości w przychodach } \\
\text { ze sprzedaży }\end{array}$ & 61,84 \\
\hline Wskaźnik udziału kosztów jakości w zysku netto & 618,25 \\
\hline Wskaźnik udziału kosztów niezgodności w zysku netto & 29,46 \\
\hline Wskaźnik udziału kosztów jakości w kosztach operacyjnych & 66,59 \\
\hline
\end{tabular}

Źródło: opracowanie własne na podstawie dokumentów wewnętrznych badanego przedsiębiorstwa.

Podsumowując analizę wskaźnikową, należy stwierdzić, że wysoki poziom kosztów jakości w stosunku do kosztów ogółem i przychodów ze sprzedaży nie jest zjawiskiem, które powinno budzić niepokój w przedsiębiorstwie. Takie proporcje wynikają z dużego zaangażowania w działania profilaktyczne, które są niezbędne w związku z prowadzoną działalnością usługową.

\section{Podsumowanie}

Rachunek kosztów jakości może być wykorzystywany przez przedsiębiorstwa jako narzędzie wspomagające proces zarządzania. Pozwala on uporządkować wiedzę na temat kosztów jakości w jednostce. Jest także cennym źródłem informacji na temat wielkości kosztów ponoszonych na zapewnienie odpowiedniego poziomu jakości, a także pojawiających się nieprawidłowości. Umożliwia identyfikację procesów, które generują największe koszty związane z jakością, a także ustalenie zależności między grupami kosztów jakości oraz wpływu kosztów jakości na wyniki finansowe i rachunek zysków i strat badanego przedsiębiorstwa. 
Wdrożenie rachunku kosztów jakości to dodatkowa szansa na zwiększenie efektywności realizowanych procesów, optymalizację kosztów, a co za tym idzie - większą efektywność całej jednostki. Przedsiębiorstwo implementujące ten rachunek uzyskuje informacje o wysokości ponoszonych kosztów jakości w realizowanych procesach, a także przyczynach powstawania niezgodności i błędów.

Głównym celem artykułu było wdrożenie rachunku kosztów jakości w wybranym przedsiębiorstwie usługowym oraz usystematyzowanie wiedzy dotyczącej rachunku kosztów jakości - jego roli w zarządzaniu przedsiębiorstwem, a także zasad jego wdrażania i szacowania kosztów jakości. Wykorzystując literaturę przedmiotu, wskazano najważniejsze korzyści, które daje jego implementacja. W świetle przeprowadzonych badań i obserwacji potwierdzono, że rachunek ten porządkuje informacje na temat kosztów jakości, wskazuje obszary problemowe, a także uwidacznia zależności zachodzące pomiędzy grupami tych kosztów oraz wynikami przedsiębiorstwa.

Na podstawie zrealizowanych badań empirycznych można wnioskować, że w wybranym przedsiębiorstwie dominują koszty profilaktyki, a tylko niewielką część stanowią pozostałe grupy kosztów jakości. Najwięcej kosztów jakości powstaje $\mathrm{w}$ procesach podstawowych, a tylko niecały procent $\mathrm{w}$ procesach pomocniczych i w procesach zarządzania. Zidentyfikowane największe nieprawidłowości w organizacji dotyczyły awarii sieci kanalizacyjnej i wycieków wody. Koszty jakości badanego przedsiębiorstwa mają duży wpływ na jego wyniki finansowe i rachunek zysków i strat.

Podsumowując, rachunek kosztów jakości przyczynia się do optymalizacji procesów i kosztów. Pozwala też zweryfikować politykę jakości w organizacji oraz może być wykorzystany jako jedno z narzędzi do oceny efektywności systemów zarządzania. Autor rekomenduje podjęcie badań, które pozwolą zweryfikować przydatność tego rachunku w prywatnych przedsiębiorstwach usługowych.

\section{Literatura}

Balon U. (2012), Zarzqdzanie kosztami jakości elementem doskonalenia organizacji (w:) Praktyka zarzqdzania jakościq w XX wieku, red. T. Sikora, M. Giemza, Wydawnictwo Naukowe PTTŻ, Kraków.

Ciechan-Kujawa M. (2004), Determinanty i bariery wdrażania rachunku kosztów jakości, „Problemy Jakości”, nr 7.

Ciechan-Kujawa M. (2005), Rachunek kosztów jakości, Oficyna Ekonomiczna, Kraków. Murumkar A.B., Teli S.N., Loni R.R. (2018), Framework for Reduction of Quality Cost, "International Journal for Research in Engineering Application and Management", Special Issue-ICSGUPSTM, https://doi.org/10.18231/2454-9150.2018.0231.

Raport roczny 2018 (2019), MPWiK w Krakowie, Kraków. 
Rehacek P. (2018), Cost of Quality or Quality Costs, ,International Journal of Advanced and Applied Sciences", vol. 5, nr 2, https://doi.org/10.21833/ijaas.2018.02.002.

Sadkowski W. (2019a), Models of Quality Costs Calculation and Their Classification, „Organization and Management”, vol. 2, nr 46.

Sadkowski W. (2019b), Przegląd dotychczasowych zastosowań modeli rachunku kosztów jakości, „Problemy Jakości”, vol. 1, nr 3, https://doi.org/10.15199/46.2019.3.3.

Stadnicka D. (2019), Wybrane metody i narzędzia doskonalenia procesów w praktyce, Oficyna Wydawnicza Politechniki Rzeszowskiej, Rzeszów.

Sulowska-Banaś U. (2013), Model rachunku kosztów jakości w samodzielnych publicznych zakładach opieki zdrowotnej, Kraków (praca doktorska).

Sulowska-Banaś U. (2015), Doświadczenia z wdrożenia rachunku kosztów jakości w szpitalu, ,Problemy Jakości”, vol. 1, nr 7-8, https://doi.org/10.15199/46.2015.7-8.7.

Wójcik G.P. (2014), Koszty jakości. Wybrane aspekty, Difin, Warszawa.

\section{Calculating Quality Costs in a Selected Service Enterprise}

(Abstract)

Objective: The article presents the calculation of quality costs, rules for its implementation and estimation, as well as an example application of this calculation in a selected service enterprise.

Research Design \& Methods: Empirical research on the practical application of a quality costs calculation was carried out in a service enterprise operating on the Kraków market. Findings: The implementation of a quality costs calculation in a selected service enterprise made it possible to provide information on quality costs and the relationships between groups of these costs as well as to indicate problem areas.

Implications / Recommendations: Advanced service processes, high customer requirements for quality services, and fierce competition mean that the cost information provided by traditional accounting systems is insufficient for the right decisions to be made in enterprises. It is therefore necessary to implement new cost accounting systems that provide reliable information on quality-related costs. Calculating quality costs as cost accounting provides authentic information about these costs, and can be used as a tool supporting the management process. The implementation of this calculation enables enterprises to increase the efficiency of the processes, optimise costs and increase overall unit efficiency.

Contribution: The results obtained should constitute the theoretical and practical basis for implementing this calculation in any service enterprise.

Keywords: quality costs, processes, quality costs calculation, management accounting. 